\title{
HRAS Gene Mutation
}

National Cancer Institute

\section{Source}

National Cancer Institute. HRAS Gene Mutation. NCI Thesaurus. Code C45934.

A change in the nucleotide sequence of the HRAS gene. 